[pre-print version of Ferreira, Nuno (2013) The EU free movement of persons from a Spanish perspective: Exploring its evolution and derogations. European Public Law, 19 (2). pp. 397-424. ISSN 1354-3725]

\title{
The EU free movement of persons from a Spanish perspective: exploring its evolution and derogations ${ }^{1}$
}

\author{
Nuno Ferreira ${ }^{2}$
}

\section{Introduction}

Spain is a recurrent case study in migration studies, both for its special characteristics and for its representativeness of a larger group of European countries, namely Greece, Italy and Portugal (González-Enríquez, 2009; González-Enríquez and Triandafyllidou, 2009; González-Enríquez, 2011). The free movement of EU citizens across Spanish borders and within Spain is, however, a matter so far insufficiently explored in legal literature. Although Spain has been a member of the EU for more than 25 years, the assessment of the implementation of EU law in this field has remained mostly limited to fairly descriptive analyses of the applicable statutory framework. This article aims to go beyond that, by looking critically at the evolution of this statutory legal framework and, above all, at its judicial application. Besides analysing the Spanish legal framework applicable to the free movement of EU citizens and their family members, this article explores a range of obstacles to that free movement.

\footnotetext{
1 This article is based on a report produced within the framework of the project "The Reconceptualization of European Union Citizenship” (2010-2012), a Multilateral Research Group financed by the Jean Monnet / Lifelong Learning Programme, led by Professor Dora Kostakopoulou (University of Southampton), and carried out in collaboration with the Centre for Migration Law (Faculty of Law, Radboud University Nijmegen) and Comillas Pontifical University (Madrid). I wish to thank Alison Morley for the thorough proof-reading.

${ }^{2}$ Senior Lecturer in Law, School of Law and Social Justice of the University of Liverpool.
} 
It concentrates particularly on the most striking obstacle to free movement: expulsion ('exclusion orders', in the terminology of the Free Movement Directive ${ }^{3}$ ). Indeed, without calling into question the need to ensure respect for legal values in each EU member state, it is striking that a legal community that is purportedly set up for its citizens and their families maintains in force legal measures typical of those applicable to foreigners (Icard, 2009: 61). Furthermore, such legal measures have arguably remained unchanged for the last 20 years, thus placing EU citizens and foreigners on the same level from the perspective of public policy, even though the principle of free movement of persons has evolved considerably during this period (Icard, 2009: 64). This article, therefore, explores in detail the statutory norms and case-law that have dealt with the possibility of expulsion of EU citizens or their family members from Spanish territory. ${ }^{4}$

Considering the judicial authority of the Spanish Supreme Court (Tribunal Supremo) and how its decisions are representative of the dominant mindset of the Spanish judiciary, the selection of case-law analysed in this article is constituted by 47 decisions of the Supreme Court. ${ }^{5}$ As these are invariably appeal decisions based exclusively on matters of law, decisions were not always clear with regard to the relevant facts, so the analysis carried out concentrates on the legal interpretation of the relevant rules.

\footnotetext{
${ }^{3}$ Directive 2004/38/EC of the European Parliament and of the Council, of 29 April 2004, on the right of citizens of the Union and their family members to move and reside freely within the territory of the Member States amending Regulation (EEC) No 1612/68 and repealing Directives 64/221/EEC, 68/360/EEC, 72/194/EEC, 73/148/EEC, 75/34/EEC, 75/35/EEC, 90/364/EEC, 90/365/EEC and 93/96/EEC.

${ }^{4}$ All legislative instruments and judicial decisions referred to throughout this article can be found on $<$ http://www.boe.es/> and <http://www.poderjudicial.es/search/index.jsp>.

${ }^{5}$ The decisions considered date up to February 2012. There are, of course, decisions relevant to the subject-matter of this article and issued by other authorities, namely Spanish lower courts; nonetheless, there are considerable obstacles to collecting and systematising these.
} 
In Section 2, this article describes the Spanish statutory legal framework applicable to the free movement of EU citizens and their family members, including the evolution undergone in this respect since Spain's accession to the EEC. Section 3 discusses in detail the grounds for limitation of free movement, including public policy, public security and public health, as well as the violation of rules concerning cards, permits and other formalities. Section 4 explores the material and formal conditions under which the grounds discussed in Section 3 may be used to create an obstacle to free movement, namely expulsion. Finally, Section 5 surveys the evolution of the case-law in this field.

\section{The statutory legal framework}

Spain signed the accession treaty to the EEC on 12 June 1985, and the treaty came into force on 1 January 1986. The first domestic statute that aimed to regulate internally the free movement of 'citizens of other member states of the European Communities' was the Free Movement Act $1099 / 1986^{6}$ (FMA 1986). The personal scope of FMA 1986 only concerned those wishing to work, either as self-employed or employed workers, and their family members. As will be seen below, courts tended to interpret this statute very strictly with the effect of reducing dramatically its personal scope.

The early 1990s saw the coming into force of Directives 90/364 on the right of residence, 90/365 on the right of residence for employees and self-employed persons who have ceased their occupational activity, and 90/366 on the right of residence for

\footnotetext{
6 'Real Decreto 1099/1986, de 26 de mayo, sobre entrada, permanencia y trabajo en España de ciudadanos de Estados Miembros de las Comunidades Europeas’.
} 
students. Also, the end of the transitional period for freedom of movement of workers between Spain and Portugal, on the one hand, and the other member states, on the other hand, was brought forward to 31 December 1991, and exceptionally 31 December 1992 with regard to Luxembourg. ${ }^{7}$ The Spanish legal system endeavoured to come into line with these Community obligations with the approval of the Free Movement Act 766/1992 ${ }^{8}$ (FMA 1992). ${ }^{9}$

After partial amendments carried out in $1995^{10}$ and $1997,{ }^{11}$ the Agreement between the EC and Switzerland on 21 June 1999 on the free movement of persons and the Declaration signed by France, Germany, Italy and Spain in Marseille on 28 July 2000 on the suppression of the obligation to possess a residence card led to the replacement of FMA 1992 with a new statute, the Free Movement Act 178/2003 (FMA 2003). This statute was the object of some judicial contention, in the light of proceedings initiated by two separate associations. A first case dealt with rules that, although allegedly aiming to prevent 'marriages of convenience', did not square easily with existing EU law. In this regard, the Supreme Court recalled Articles 10

\footnotetext{
${ }^{7}$ Council Regulation (EEC) No 2194/91 of 25 June 1991. Initial dates were 31 December 1992 and 31 December 1995 respectively.

8 'Real Decreto 766/1992, de 26 de junio, sobre entrada y permanencia en España de nacionales de Estados miembros de las Comunidades Europeas'.

9 This statute became the object of litigation at the ECJ level, when the Commission lodged a complaint against Spain and alleged the illegality of Article 10(3), which required non-EU family members of EU citizens to produce a residence visa in order to obtain a residence permit. The ECJ found the Commission's complaint to be well founded (Case C-157/03, Commission of the European Communities v Kingdom of Spain, 14/4/2005).

10 'Real Decreto 737/1995, de 5 de mayo, por el que se modifica el Real Decreto 766/1992, de 26 de junio, sobre entrada y permanencia en España de nacionales de Estados miembros de las Comunidades Europeas', following the ratification by Spain of the Agreement on the European Economic Area and of the Treaty on European Union, as well as the ECJ jurisprudence (namely its decision in Case 267/83, Aissatou Diatta $v$ Land Berlin, 13/2/1985).

11 'Real Decreto 1710/1997, de 14 de noviembre, por el que se modifica parcialmente el régimen de entrada y permanencia en España de nacionales de estados miembros de la Unión Europea y de otros Estados partes en el acuerdo sobre el Espacio Económico Europeo', following the procedure by the Commission against Spain pertaining to residence cards for individuals not carrying out economic activities or studies, as well as requirements to be fulfilled by individuals wishing to study in Spain.

12 'Real Decreto 178/2003, de 14 de febrero, sobre entrada y permanencia en España de nacionales de Estados miembros de la Unión Europea y de otros Estados parte en el Acuerdo sobre el Espacio Económico Europeo’.
} 
and 12 of Regulation 1612/68, Directive 180/1990, Article 8 ECHR, and ECJ decisions in Diatta, ${ }^{13}$ Baumbast ${ }^{14}$ and Aikrich. ${ }^{15}$ The Supreme Court found the contested rules to be incompatible with these legal sources, and annulled the requirements in question. ${ }^{16}$ A second case dealt with the automatic indication of a deadline to leave the country simultaneously with the denial of a residence card. Again, the Court sided with the claimant and amended the provision in question. ${ }^{17}$ The Court reasoned on the basis of the ECJ decisions in Royer $^{18}$ and in MRAX. ${ }^{19}$ These Decisions indicated a growing alignment with EU (and ECHR) rights and, consequently, a greater readiness to protect the right to free movement of EU citizens and their family members. This is consistent with Spanish scholarship that has found that Spanish membership of the EU has, indeed, Europeanised Spanish (statutory and judicial) legal standards in the light of European criteria, standards and procedures, namely in the light of the principles of supremacy and direct effect of EU law and national judges as ‘EU natural judges’ (Closa and Heywood, 2004: 78-82; Vilà-Costa, 2011).

Further evolution in the jurisprudence of the ECJ and the approval of the Free Movement Directive in 2004 prompted the Spanish legislature to replace FMA 2003 with a new statute: Free Movement Act 240/2007²0 (FMA 2007). This statute,

${ }^{13}$ Case 267/83, Aissatou Diatta v Land Berlin, 13/2/1985.

${ }^{14}$ Case C-413/99, Baumbast, $R$ and Secretary of State for the Home Department, 17/9/2002.

${ }^{15}$ Case C-109/01, Secretary of State for the Home Department and Hacene Akrich, 23/9/2003.

${ }^{16}$ STS 3999/2004 (10/6/2004).

17 STS 732/2005 (9/2/2005).

${ }^{18}$ Case 48-75, Jean Noël Royer, 8/4/1976.

${ }^{19}$ Case C-459/99, Mouvement contre le racisme, l'antisémitisme et la xénophobie ASBL (MRAX) and État belge, 25/7/2002.

20 'Real Decreto 240/2007, de 16 de febrero, sobre entrada, libre circulación y residencia en España de ciudadanos de Estados miembros de la Unión europea y de otros Estados parte en el Acuerdo sobre el Espacio Económico Europeo’. This legal instrument transposed the Free Movement Directive with almost ten months' delay, as the deadline for implementation was 30 April 2006 (Article 40 Free Movement Directive). Despite this delay, and a significant number of complaints and letters of notice from the Commission with regard to inadequate transposition of directives, since 2004 Spain can still be considered to generally transpose directives within the deadline (Mullerat, 2011: 96). FMA 2007 
together with a range of other secondary legislative instruments, constitutes the statutory legal framework currently applicable to EU citizens and their family members. Although this legal framework constituted an overall positive step, it contained rules which were the object of widespread and deserved criticism. Amongst these it is worth mentioning, in particular, the obligation for all EU citizens wishing to reside in Spain for more than three months to register with the Central Registry of Foreigners (Article 7(1) FMA 2007) which, according to Peinado, constitutes a regression in relation to the previous legal framework (Peinado, 2007: 612). Most other points of contention, however, have been resolved by the Spanish Supreme Court, following a period of strong scholarly criticism (Peinado, 2007; Sánchez, 2007; González Viada, 2009).

Indeed, the present version of FMA 2007 includes amendments imposed by the Supreme Court in Decision No. 4259/2010, ${ }^{21}$ where the Court dealt with a request to suspend some provisions in FMA 2007. The main provisions and issues in question related to whether: (i) the statute’s personal scope included Spanish citizens' relatives, legally separated but not divorced individuals, and partners who had celebrated their partnership in a country allowing two simultaneous registrations; (ii) dependent descendants over the age of 21 and dependent ascendants had the right to work; (iii) surviving relatives of EU/EEA citizens wishing to retain the right to reside in Spain (and who did not yet possess a permanent right to reside) should be exempted from the obligation to request a residence permit; (iv) the urgent character of an expulsion should not prevent the judicial control of administrative decisions expelling EU

was soon amended by Royal Decree 1161/2009, 10 July, to add a second paragraph to Article 4(2) FMA 2007, to duly implement Article 5(2) Free Movement Directive with regard to exempting from visa requirements those family members who are not nationals of a EU member state but who possess a valid residence card. González Viada had pointed out the deficient transposition of this Directive provision (González Viada, 2009).

${ }^{21}$ STS 4259/2010 (1/6/2010). 
citizens or family members; and, finally, (v) all relatives in direct or collateral lines should also have the right to residence permits. The Supreme Court answered affirmatively to all these claims, finding support in Free Movement Directive provisions. It consequently either annulled or amended all contested FMA 2007 provisions, ${ }^{22}$ again confirming the pervasive legal Europeanisation of the Spanish legal system (Closa and Heywood, 2004: 78-82; Vilà-Costa, 2011). This Supreme Court decision consistently held in favour of broadening the scope of FMA 2007, consequently promoting a liberal view of the free movement of persons and preventing a restrictive implementation of the Free Movement Directive. This reflects an overall generous approach to the EU free movement of persons in the most recent years, a conclusion that will be reinforced by the case-law analysis below.

More recently, FMA 2007 underwent changes by the Amending Act 1710/2011, ${ }^{23}$ in particular its Articles 8(4) (regarding the residence card of EU citizens' family members), 9(4) (concerning the rights of EU citizens' family members when the family relationship undergoes changes), 15(2) (concerning the deadline to request the lifting of prohibition of entrance), and 18(2) (regarding the deadline to enforce expulsion orders), and by introducing a new paragraph 5 to Article 9 (regarding evidentiary procedures without systematic character) and a new paragraph 4 to Article 14 (regarding the use of any legally admissible means to prove one's residence rights under EU law). Overall, the amendments introduced by the

\footnotetext{
${ }^{22}$ Yet, this decision was not unanimous. A vote of dissent by Teso Gamella argued that EU member states withheld a considerable 'margin of appreciation' (to import into this context the notion used in the jurisprudence of the ECtHR) when implementing EU directives, and that the provisions contested should, therefore, only have been annulled if they were useless, or contradicted or harmed the objectives of the Directive they aimed to implement. This position, however, seems to rely on a very conservative, if not outdated, reading of the jurisprudence of the CJEU.

23 'Real Decreto 1710/2011, de 18 de noviembre, por el que se modifica el Real Decreto 240/2007, de 16 de febrero, sobre entrada, libre circulación y residencia en España de ciudadanos de Estados miembros de la Unión europea y de otros Estados parte en el Acuerdo sobre el Espacio Económico Europeo'.
} 
Amending Act are positive, to the extent that they clarify the wording previously in force, in most instances expanding the rights of EU citizens and their family members or at least offering them greater legal certainty. The only amendments that warrant closer attention are Articles 15(2) and 18(2), which are discussed in greater detail below.

The legislation directly related to the circulation of EU citizens and their family members is supplemented by other legislative instruments related to foreigners in general, but only to the extent that these are beneficial to EU citizens and their family members, and do not contradict the EU treaties. These instruments include: the Rights and Freedoms of Foreigners Framework Act ${ }^{24}$ and its Regulating Act, ${ }^{25}$ a legal framework generally held as liberal and as expanding immigrant rights (Gonzalez and Mac Bride, 2000); and general statutes on public administration, such as the Public Administration and Procedure Act, ${ }^{26}$ and the Exercise of Sanctioning Powers Act. ${ }^{27}$

Considering the current statutory legal framework, let us look into how free movement of persons to/in/from Spain may be subject to limitations on a range of grounds.

\section{Grounds for limitation of free movement}

FMA 2007 establishes in Articles 15-18 the conditions under which public policy, public security and public health may be invoked to limit the free movement of EU

\footnotetext{
24 'Ley Orgánica 4/2000, de 11 de enero, sobre derechos y libertades de los extranjeros en España y su integración social’.

25 'Real Decreto 2393/2004, de 30 de diciembre, por el que se aprueba el Reglamento de la Ley Orgánica 4/2000, de 11 de enero, sobre derechos y libertades de los extranjeros en España y su integración social’.

26 'Ley 30/1992, de 26 de noviembre, de Régimen Jurídico de las Administraciones Públicas y del Procedimiento Administrativo Común’.

27 'Real Decreto 1398/1993, de 4 de agosto, por el que se aprueba el Reglamento del Procedimiento para el Ejercicio de la Potestad Sancionadora'.
} 
citizens and their family members. These grounds may be used to impede the entrance of EU citizens and their family members into Spanish national territory, deny their enrolment onto the Central Registry of Foreigners, and expel them from national territory. Case-law related to these individual grounds is explored in greater detail below (Section 5); the relevant statutory provisions are discussed in the following paragraphs.

Spanish legislation has translated the notion of public policy into domestic law as public order; both expressions will thus be used interchangeably throughout this article. The notion of public order is inherently loose and indeterminate, so as to offer a flexible legal and policy instrument to member states' public authorities. Although it is not possible to determine its exact content, it undoubtedly includes violations of domestic law provisions, namely criminal law provisions.

Public security, together with public order, seem to be the highest-ranked grounds, in the sense that they are the only grounds on which expulsion may be justified even if the individual in question is entitled to permanent residence in Spain (Article 15(1) FMA 2007). The distinction between public security and public order is not clear from the wording of the statute, nor do other relevant rules solve this lack of clarity either. For example, the Protection of Citizens' Security Framework Act ${ }^{28}$ seemingly regulates the protection of public security; however, activities mentioned in this statute are referred to as violations of public order by Article 53(1)(f) Rights and Freedoms of Foreigners Framework Act. The blurring of the distinction is compounded by the reference in Article 27(3) Free Movement Directive (transposed by Article 12(3) FMA 2007) to the possibility of requesting other member states to

\footnotetext{
28 'Ley Orgánica 1/1992, de 21 de febrero, sobre Protección de la Seguridad Ciudadana’.
} 
supply existing police records to assess any possible danger to public policy or public security, thus linking both notions to past or present criminal activity.

Furthermore, Spanish authorities can invoke national security to prevent EU citizens and their family members from leaving the Spanish territory (Article 5 FMA 2007). Although not defined, and despite remaining different notions, national security seems to be closely related to, and overlap considerably with, the notion of public security. Moreover, whilst national security may justify a prohibition to leave the country and this seems to correspond to the committing of ordinary criminal offences (Article 28 Rights and Freedoms of Foreigners Framework Act and Article 20 Regulating Act), administrative and judicial authorities tend to refer to public order when justifying expulsion orders on grounds of committing similar criminal offences. ${ }^{29}$ Public order, public security and national security thus seem to be used interchangeably: they are amorphous and overlapping categories, which most often are applied concomitantly and in an unspecified manner. One way of making sense of the way these grounds are statutorily regulated and judicially applied is to favour the use of the public order ground for less serious offences and the public/national security ground for offences which may actually have a palpable impact on the wellbeing of the general population. Yet, not even this approach may satisfactorily explain all aspects explored in the case-law analysis (Section 5).

The public health ground, besides constituting a ground for prohibiting the entrance into and for ordering the expulsion from Spanish national territory, can also be used by the authorities to prevent EU citizens and their family members from leaving Spanish territory (Article 5 FMA 2007). Only diseases or medical conditions

${ }^{29}$ STS 14268/1993 (8463/1994, 18/5/1993), STS 17205/1993 (=8878/1993, 17/12/1993), STS (ATS) 3056/1994 (=1848/1994, 24/1/1994), STS 1715/2000 (4/3/2000), STS 6394/2000 (20/7/2001). 
with an epidemic potential may be used as a basis for these measures (Article 15(9) FMA 2007). Such diseases and medical conditions are only those defined as such by the World Health Organization, or those infectious or contagious parasitic conditions in accordance with Spanish domestic law, which is in line with Article 29(1) Free Movement Directive. ${ }^{30}$ Also, and in keeping with Article 29(2) Free Movement Directive, Article 15(9) FMA 2007 adds that those diseases that occur after a threemonth period from the date of arrival of the individual in question may not justify an order of expulsion. Moreover, and as a way of implementing Article 29(3) Free Movement Directive, Spanish authorities are entitled to require individuals to present a medical certificate establishing their state of health and/or undergo medical examinations free of charge to certify they do not suffer from any of the conditions that may give rise to an expulsion order; this may only occur, however, in individual cases in relation to which there are serious indications, and may not be done routinely (Articles 12(4) and 15(9) FMA 2007).

Finally, and in line with EU law developments, the importance of cards, permits and other formalities has greatly diminished, thanks to both the judiciary and the legislature. Courts have asserted that only a fine - and not expulsion - is suitable for the violation of documentation formalities, ${ }^{31}$ and have ensured that EU citizens are not required to present a visa or obtain a formal visa exemption. ${ }^{32}$ The current legislation also makes it clear that not possessing a valid passport or identity card, or a

\footnotetext{
${ }^{30}$ Article 15(9) FMA 2007 replaced Article 16(2)(c) FMA 2003, which instead referred to diseases that warrant quarantine according to the International Sanitary Regulations. The Directive and current domestic law provisions arguably offer slightly more flexibility to national authorities than the previous rule did.

31 STS $1676 / 1993(=18905 / 1993,16 / 3 / 1993)$, STS $13779 / 1993(=2571 / 1993,23 / 4 / 1993)$, STS 2858/1993 (=13943/1993, 7/5/1993), STS (ATS) 196/1993 (=4140/1993, 21/9/1993), STS 7727/1993 (16/11/1993), STS (ATS) 5285/1994 (=18/1994, 28/2/1994), STS 20515/1994 $(=12286 / 1994$, 31/5/1994), STS (ATS) 1442/1994 (=4495/1994, 11/7/1994), STS (ATS) 1731/1994 (=4574/1994, 27/9/1994), STS 6320/1995 (12/12/1995), STS (ATS) 6685/1997 (20/1/1997), STS 2434/2002 (5/4/2002), STS 630/2008 (12/2/2008), STS 2623/2008 (29/5/2008).

${ }^{32}$ STS 125/1996 (16/1/1996).
} 
residence card, may not justify an order of expulsion (Article 15(7) FMA 2007). Similarly, not complying with the obligation to apply for a residence card or to register may only lead to pecuniary penalties of the same nature as those imposed on Spanish citizens with regard to the Spanish national identity card (Article 15(8) FMA 2007). Nonetheless, and despite being under an obligation to offer 'the maximum facilities to obtain or receive within a reasonable period of time the necessary documents, or to corroborate or prove by other means that they are covered by the scope of application of the statute' (compatible with Article 5(4) Free Movement Directive), Article 4(4) FMA 2007 allows public authorities to deny entrance into Spanish territory on grounds of expiry of passport or identity card; this has been criticised as excessive by González Viada (González Viada, 2009).

\section{Material and formal conditions to limit free movement}

\section{a) Material conditions}

The conditions under which the grounds for limitation of free movement (especially expulsion) may be invoked by Spanish authorities have been established statutorily and judicially. When expelling EU citizens and their family members (as well as impeding entrance into Spanish national territory and denying enrolment onto the Central Registry of Foreigners), authorities are, first of all, required to consider the length of residence and social and cultural integration of the individual in question in Spain, his/her age, state of health, family and economic situation, and possible links with country of origin (Article 15(1) FMA 2007). The need to consider these elements has been stated immediately after a phrase related to the expulsion of those EU 
citizens and their family members with a permanent right to reside in Spain. This is unfortunate since, based on a sort of systematic interpretation element, it may lead to a restrictive interpretation to the effect of only requiring the consideration of the elements mentioned above in the case of EU citizens and their family members with a permanent right of residence in Spain, and not in all cases of expulsion of an EU citizen or family member (as required by Article 28 Free Movement Directive).

Secondly, authorities are also required to respect the legislation regulating public order and public security (Article 15(5)(a) FMA 2007). It remains, however, unclear to what legislation this expression refers. Indeed, neither FMA 2007 nor any other statute clarifies what is the 'legislation regulating public order and public security', so it seems to be up to each individual decision-maker to decide to what provisions and instruments this expression refers, rendering Article 15(5)(a) FMA 2007 relatively ineffective. Thirdly, and as determined by Article 27(1) Free Movement Directive, authorities should not adopt measures with economic objectives (Article 15(5)(c) FMA 2007).

Most crucially, in the case of measures taken on grounds of public order or public security, Article 15(5)(d) FMA 2007 establishes that: (i) authorities have to found the measures exclusively on grounds related to the conduct of the individual subject to the measure, (ii) such individual conduct must constitute a genuine, present and sufficiently serious threat affecting one of the fundamental interests of society, and (iii) the existence of previous criminal convictions may not, on their own, constitute sufficient grounds for such a measure. ${ }^{33}$ The importance of the conditions

\footnotetext{
${ }^{33}$ Courts have, however, initially paid little attention to this rule. They would either deny its application altogether (for example, Article 22(2) FMA 1986) by not applying the statute applicable to EU citizens at all (for example, STS 16452/1990=7613/1990, 24/10/1990; STS 13677/1993, 29/1/1993), or apply this statute but still not pay due attention to the (insufficient) relevance of previous criminal convictions (STS (ATS) 8116/1998, 22/6/1998, arguing that the insufficient relevance of previous criminal
} 
laid down in Article 15(5)(d) FMA 2007 was borne out by the ECJ decision in Commission v Spain (C-503/03), ${ }^{34}$ which accounts for such close implementation of Article 27(2) Free Movement Directive. Yet, the latter provision also states that '[j]ustifications that are isolated from the particulars of the case or that rely on considerations of general prevention shall not be accepted', and this has not been expressly implemented by FMA 2007 or elsewhere in Spanish statutory law.

Under certain circumstances, the conditions that have to be met to impose a measure limiting the freedom of movement of EU citizens and their family members are stricter. In the case of EU citizens or family members with a permanent right to reside in Spain, only (serious) grounds of public security and public order may be used to justify a decision of expulsion (Article 15(1) FMA 2007). Furthermore, as provided by Article 28(3) Free Movement Directive, Article 15(6) FMA 2007 prohibits expulsion orders, unless there are 'imperative grounds of public security', in the case of a subject of the order who has lived in Spain during the previous ten years or is a minor, unless the expulsion is in the minor's best interests.

convictions was a new matter not previously raised, so it could not be considered at the level of appeal; this is an arguably deficient reasoning, as this matter is an essential legal element to be considered in any decision regarding an expulsion order based on a criminal record, so it should have been considered by the lower court and should be subject to analysis by the higher court in an appeal on matters of law). More positive examples of the application of this rule can be seen in later decisions: STS 13474/1993 (30/4/1993), STS 14268/1993 (=8463/1994, 18/5/1993), STS (ATS) 3056/1994 $(=1848 / 1994,24 / 1 / 1994)$, appealed decision in STS $21602 / 1994(=10235 / 1994,23 / 3 / 1994)$, STS $1715 / 2000$ (4/3/2000), STS 2032/2000 (14/3/2000), STS 6394/2000 (20/7/2001). Also, it is worth noting that this rule was previously contained in Article 22(2) FMA 1986, but then omitted in FMA 1992 and FMA 2003.

${ }^{34}$ Case C-503/03, Commission of the European Communities v Kingdom of Spain, 31/1/2006, which involved two Algerian citizens married to Spanish citizens and wishing to enter Spain. The individuals in question were refused visas and entry into Spain due to being the subjects of alerts in the list of persons not to be permitted entry into the Schengen Area according to the Schengen Information System ('SIS'), without the reasons behind such alerts and refusals being specified. Following a complaint by the Commission, the ECJ asserted that the Spanish authorities had an obligation to enquire about the reasons for the alerts from the member states issuing them, as well as verifying that the presence of these individuals indeed constituted a genuine, present and sufficiently serious threat affecting one of the fundamental interests of society (paras. $53 \mathrm{ff}$ ). This decision was taken when FMA 2003 was still in force, and this statute did not include any wording to the effect of requiring individual conduct to 'constitute a genuine, present and sufficiently serious threat affecting one of the fundamental interests of society'; FMA 2007, however, has included it, which should prevent similar instances of litigation from happening in the future. 
The Rights and Freedoms of Foreigners Framework Act also determines that expulsion orders are subject to the principle of proportionality (Article 57), a principle applicable to EU citizens and their family members in the light of the jurisprudence of the CJEU. ${ }^{35}$ To the extent that this principle may have a positive impact on decisions regarding those within the personal scope of FMA 2007 (and if such impact does not necessarily derive from the rules established in the latter statute), then it should also apply to the expulsion of EU citizens and their family members. The same provision adds that expulsion orders may not be addressed to certain categories of people. ${ }^{36}$ Since this rule can be held beneficial to those falling under the personal scope of FMA 2007 (and arguably more beneficial to them in some regards than the more general provisions contained in FMA 2007), it should apply in addition to them. ${ }^{37}$ Furthermore, Article 64(2) Rights and Freedoms of Foreigners Framework Act allows for an extension of the deadline to leave Spain and the postponement or suspension of

\footnotetext{
${ }^{35}$ For example, Case 118/75, Lynne Watson and Alessandro Belmann, 7/7/1976; and Cases C-482/01 and C-493/01, Georgios Orfanopoulos, Natascha Orfanopoulos, Melina Orfanopoulos, Sofia Orfanopoulos and Land Baden-Württemberg (C-482/01), and between Raffaele Oliveri and Land Baden-Württemberg (C-493/01), 29/4/2004.

${ }^{36}$ Namely: (i) individuals born in Spain and legally resident in Spain for the previous five years; (ii) long-term residents, when considering their length of residence, links created with Spain, age, consequences for the individuals and their family, and links with the state to which they are to be expelled; (iii) individuals who were originally Spanish citizens and have lost their nationality; (iv) individuals who are recipients of benefits because of incapacity for full-time work due to a work accident or work-related illness occurred in Spain, or who are recipients of job-seekers' allowance or an allowance to support social or work (re)integration; (v) spouses of individuals mentioned in the previous item and legally resident in Spain for more than two years, as well as ascendants, descendants under age, and adult descendants objectively lacking the capacity to provide for themselves on grounds of ill health, when such persons are the responsibility of the individuals mentioned in the previous item; and (vi) pregnant women, when the expulsion would create a risk to the pregnancy or the pregnant woman's health.

37 This provision also determines that individuals who find themselves in Spain and are long-term residents of another EU member state may only be expelled to outside the EU after the long-term residence EU member state is consulted and if the conduct in question falls under certain particularly serious categories. If these requirements are not fulfilled, then the individual in question may only be expelled to the long-term residence EU member state. This may not be of interest to EU citizens, as it expressly only applies to non-EU citizens; however, it is of interest to those non-EU citizens who, besides benefiting from the protection of FMA 2007 (for being a family member of an EU citizen in Spain), may prefer to return to the long-term residence EU member state rather than to their (non-EU) state of nationality.
} 
an expulsion order under certain circumstances. ${ }^{38}$ This rule, being beneficial to EU citizens and their family members, and not being replicated by any provision in FMA 2007, should also apply to these individuals.

\section{b) Formal conditions}

In addition to this set of material conditions, the Spanish legal system clearly places considerable weight on the procedural safeguards to which EU citizens and their family members are entitled. ${ }^{39}$ Due process and procedural justice are legally guaranteed, in the light of the supplementary application of the Rights and Freedoms of Foreigners Framework Act, its Regulating Act, and the Public Administration and Procedure Act. These statutes enshrine, among others, the right to: access files and obtain copies of them; identify the authorities and the employees responsible for the procedure; submit allegations and documents at any moment of the procedure up to the final oral hearing; ${ }^{40}$ obtain legal information and guidance as to legal and technical requirements; have access to the legal reasoning on which acts affecting one's subjective rights or legitimate interests are based; be notified of such acts in writing; appeal against such acts; submit any legally admissible evidence; be

\footnotetext{
${ }^{38}$ Namely: (i) family unity with the family members remaining in Spain; (ii) need for urgent medical services or basic medical treatment of a disease; (iii) access by children to elementary schooling, depending on the length of residence; and, (iv) special needs of vulnerable persons.

39 This was, however, not always the case. For example, in its Decision No. 2/1992, the Spanish Constitutional Court (Tribunal Constitucional) refused the claim of violation of procedural safeguards, revealing an insufficient concern for procedural safeguards due in the case of expulsion of EU citizens. In previous decisions, courts had at least recognised the violation of the procedural safeguards established statutorily, even if only then to argue that these irregularities had been corrected subsequently. In this instance, however, the Constitutional Court seemed to lower the threshold and accept a less than optimal level of protection of the procedural rights of the claimant.

${ }^{40}$ Nonetheless, the right to be present and submit one's defence personally at the oral hearing of an appeal may be limited on grounds of serious reasons of public order or public security, and where the appeal refers to the prohibition of entrance (Article 17(2) FMA 2007, implementing Article 31(4) Free Movement Directive).
} 
presumed innocent; have access to legal aid and an interpreter; present administrative and judicial appeals via diplomatic or consular representatives; and have legal standing as an association, ${ }^{41}$ as well as the principles of effective judicial protection, proportionality, enforcement of acts in the least restrictive way possible, and respect for individuals' fundamental rights. ${ }^{42}$

FMA 2007 ensures that EU citizens and their family members enjoy greater rights than those generally available, by offering more stringent procedural safeguards in consonance with the Free Movement Directive. These procedural safeguards have been further entrenched in the law by the Supreme Court in its Decision No. 4259/2010, ${ }^{43}$ whereby it amended Article 18 FMA 2007 with the effect of ensuring that decisions determining the expulsion of an EU citizen establish a deadline by which the citizen in question has to leave the national territory, even in a case of urgency. In other words, the right to a justification of the decision of expulsion, on the one hand, and the right to be notified of the decision and the possibility to appeal, on the other hand, should not be undermined on grounds of urgency. With this decision, the Supreme Court confirmed the central role of procedural safeguards and the principle of due process.

Article 4(3) FMA 2007 establishes that any decision denying entrance to an individual falling within the personal scope of this statute needs to be justified. Such decision should include the precise reasons why that individual has not been allowed entrance into Spanish national territory: either for not fulfilling the requirements

\footnotetext{
41 Articles 20, 21, 22 and 65(2) Rights and Freedoms of Foreigners Framework Act; Article 139 Regulating Act; Articles 35, 37, 54, 55, 58, 80, 84, 107, 135, 137 and 138 Public Administration and Procedure Act.

42 Articles 62, 96, 100 and 131 Public Administration and Procedure Act; Article 20 Rights and Freedoms of Foreigners Framework Act. Examples of upholding of legal procedural safeguards and effective legal protection by Courts can be seen in STS 7948/1993 (=16963/1993, 23/11/1993), STS $17205 / 1993$ (=8878/1993, 17/12/1993), STS 1356/1996 (4/3/1996), STS 8776/2007 (27/11/2007), STS 4079/2008 (10/7/2008).

${ }^{43}$ STS 4259/2010 (1/6/2010, discussed above), in particular points 9 and 10 .
} 
established in FMA 2007 or on grounds of public order, public safety or public health. The only exception to the obligation to communicate such reasons to the individual in question relates to state security. Similarly, Article 18(2) FMA 2007 establishes that expulsion orders have to be justified, and have to inform individuals of their right to appeal, as well as provide details of relevant appeal bodies and deadlines. Furthermore, according to Article 26(2) Rights and Freedoms of Foreigners Framework Act and Article 13 Regulating Act, decisions impeding the entrance of foreigners need to be justified and notified, and include information about the possibility of appeal, relevant deadlines and appeal bodies, and the right to an interpreter. To the extent that this supplementary legal framework may add some beneficial element to the rules established by FMA 2007 (such as the right to an interpreter), then it should apply to EU citizens and their family members as well.

With regard to orders of expulsion of citizens in possession of a residence card or certificate, Article 16 FMA 2007 establishes that, except in cases of urgency, the opinion of the State Attorney (Abogacía del Estado) of the province in question should be sought by the administrative authorities before they issue the expulsion order. The same provision adds that, upon request of the individual in question, administrative authorities' orders of expulsion of EU citizens or family members who have requested a residence card or registry certificate are submitted to the analysis of the State Legal Services (Dirección del Servicio Jurídico del Estado) or the State Attorney of the province. Although this consultation stage is additional to the right to administrative and judicial appeals, it creates a three-tiered hierarchy of EU citizens and family members subject to expulsion:

i. a first, better protected, group of EU citizens and family members who possess a residence card or registry certificate, whose expulsion order is 
subject to the legal opinion of the State Attorney automatically, except in urgent cases;

ii. a second, less protected, group of EU citizens and family members who do not possess, but have requested a residence card or registry certificate, whose expulsion order may be subject, upon request of the individual in question, to the legal opinion of the State Legal Services or State Attorney;

iii. a third, least protected, group of EU citizens and family members who neither possess nor have requested a residence card or registry certificate, whose expulsion order is not subject, even upon request of the individual in question, to the legal opinion of the State Legal Services or State Attorney.

Yet, the lack of a residence card (as well as of a valid passport or identity card) does not warrant an order of expulsion (Article 15(7) FMA 2007, discussed above) and such document is nowadays consensually seen as merely declaratory, and not constitutive of the right to reside in another EU member state. That being so, it is difficult to understand why the same obligation to seek the State Attorney's opinion does not apply to the expulsion of those citizens not in possession of, and who have not requested, a residence card or registry certificate. The justification for this different level of procedural safeguard is not at all transparent.

Considering the consequences of an expulsion order, the importance of being able to request its suspension is clear. This importance is reflected in the number of Supreme Court cases involving requests to suspend expulsion orders issued against EU citizens and family members. ${ }^{44}$ Consequently, Article 17(1) FMA 2007, following

${ }^{44}$ STS (ATS) 2660/1992 (=432/1992, 18/3/1992), STS (ATS) 2706/1992 (=433/1992, 15/7/1992), STS (ATS) 196/1993 (=4140/1993, 21/9/1993), STS (ATS) 4008/1993 (=1624/1993, 27/10/1993), STS (ATS) 3056/1994 (=1848/1994, 24/1/1994), STS (ATS) 5285/1994 (=18/1994, 28/2/1994), STS (ATS) 
Article 31(2) Free Movement Directive, addresses this matter by stating that, when an appeal against an order of expulsion is accompanied by a request to suspend the order's enforcement, the expulsion may not be enforced until a decision on the suspension request is reached, unless: the expulsion is based on a previous judicial decision; the individuals affected had already had access to judicial review; or the expulsion order is based on imperative grounds of public security.

Respecting the minimum period imposed by Article 30(3) Free Movement Directive, Article 18 FMA 2007 also establishes that expulsion orders must not set a deadline to leave the country of less than one month; the only exception concerns the circumstances mentioned in Article 17 of the same statute (discussed in the previous paragraph), in which case the administrative or judicial control of the order in question is still safeguarded. ${ }^{45}$ Also, according to the legal framework applicable to non-EU foreigners, the deadline to leave the country may still be as short as 72 hours (Article 141(7) Regulating Act), which highlights the preferential treatment offered to those falling under the personal scope of FMA 2007.

EU citizens and their family members who have been expelled and prohibited from entering ${ }^{46}$ Spanish territory are also guaranteed the right to request that the prohibition of entrance be lifted, on grounds of material changes to the reasons that

1442/1994 (=4495/1994, 11/7/1994), STS (ATS) 4554/1994 (=1727/1994, 20/9/1994), STS (ATS) $1740 / 1994$ (=4447/1994, 26/9/1994), STS (ATS) $1731 / 1994$ (=4574/1994, 27/9/1994), STS 849/1995 (=8622/1994, 17/2/1995), STS 6320/1995 (12/12/1995), STS 1356/199 (4/3/1996), STS 790/1996 (9/12/1996), STS (ATS) 6685/1997 (20/1/1997), STS 5986/2000 (18/7/2000).

${ }^{45}$ As mentioned when discussing Decision No. 4259/2010 (1/6/2010), Article 18 FMA 2007 initially established that expulsion orders could be carried out without delay in cases of duly justified urgency, but the Supreme Court annulled this phrase. The Amending Act reintroduced the possibility of expulsion orders establishing a deadline shorter than a month, although only in the case of the circumstances listed, and safeguarding the possibility of review of the decision.

${ }^{46}$ Based on Article 58 Rights and Freedoms of Foreigners Framework Act and Article 139(c) Regulating Act, expulsion orders must be accompanied by prohibitions of entrance into national territory for periods between three and five years and, exceptionally, in the case of a serious threat to public order, public security, national security or public health, ten years (extending to other states with which Spain may have agreements to this effect). FMA 2007 does not include any provision determining the duration of the prohibition of entrance into the country, so these provisions may apply. 
led to the prohibition. According to Article 15(2) FMA 2007, as altered by the Amending Act, such request may be presented after a reasonable period (to be determined by the competent authorities and in the light of the relevant circumstances), and in any case after three years since the enforcement of the decision in question. ${ }^{47}$ Also, consistent with Article 33(2) Free Movement Directive, Spanish authorities are obliged to review any possible changes to the relevant circumstances and the subsistence of a threat to public order or public security, every time an order of expulsion is executed more than two years after having been decided (Article 15(4) FMA 2007). ${ }^{48}$

One may therefore conclude that the Free Movement Directive has been comprehensively and sufficiently implemented into the Spanish legal framework with regard to the formal conditions that have to be in place to limit free movement. It has been argued by González Viada, Carrera and Anaïs that Spanish law fails to thoroughly implement some aspects of the Free Movement Directive, namely its Articles 30(1) (requiring written notification of decisions), 30(2) (requiring the persons concerned to be informed, precisely and in full, of the public policy, public

\footnotetext{
${ }^{47}$ In the original (2007) version of this rule, the request could, however, only be presented at least two years after the prohibition. The Spanish legislature had thus implemented the notion of 'reasonable period' under Article 32 Free Movement Directive as two years. Although the original version has been considered more beneficial for EU citizens than the Directive's provision (Peinado, 2007: 619), it is submitted that the wording introduced by the Amending Act, by adhering more closely to the Directive's wording, is in fact more beneficial, as the 'reasonable period' determined by the competent authorities may be much shorter than two years. Also, whilst the Directive provision refers to the 'enforcement of the final exclusion', the original Spanish provision counted the two-year period from the 'prohibition'. It was not entirely clear if the 'prohibition' (exclusion) referred to the moment of the decision or its enforcement, which could have led to legal argument. By adopting the exact wording of the Directive, the new version of Article 15(2) FMA 2007 introduced by the Amending Act precludes any potential claim of deficient implementation.

${ }^{48}$ Articles 15(2)(b) FMA 1992 and 16(2)(b) FMA 2003, no longer in force, stated that measures taken on public order, public security or public health grounds could be revoked, both ex officio and upon request by the interested party, if the reasons giving rise to the measure in question no longer existed. These rules seem more generous than the ones currently in force since, contrary to the latter, the former rules apparently did not require individuals to wait for two years until being allowed to request a review of their circumstances, nor did they allow authorities to ignore such changes for a similar period of two years.
} 
security or public health grounds on which decisions concerning them are based), and 31(3) (requiring redress procedures to allow for an examination of the legality of the decision, as well as of the facts and circumstances on which the proposed measure is based) (Carrera and Anaïs, 2009: 13; González Viada, 2009). Although the exact wording of the FMA 2007 rules could admittedly be more explicit in their implementation of these Free Movement Directive articles, the procedural safeguards in question are arguably already protected by the rights and principles enshrined in the Rights and Freedoms of Foreigners Framework Act, its Regulating Act, and the Public Administration and Procedure Act, discussed at the beginning of this section and all of which are considered to contribute towards the implementation of the Free Movement Directive into Spanish law. ${ }^{49}$

\section{The Supreme Court case-law on EU free movement of persons}

National courts play an essential role in the implementation of the EU and national statutory frameworks applicable to the free movement of EU citizens. Above all, the interpretation of the notions of public policy and public security ultimately depends on national courts, even if within the limits imposed by the CJEU. This national judicial activity thus translates the true legal conscience experienced in each EU member state, thereby warranting a close analysis.

\section{a) Figures and statistics}

\footnotetext{
$49 \stackrel{\text { See }}{\text { lex.europa.eu/LexUriServ/LexUriServ.do?uri=CELEX:72004L0038:EN:NOT\#FIELD_ES>, accessed }}$ 20 June 2012.
} 
There are no publicly available statistics on the number of expulsions of EU citizens or their family members or, more generally, of the incidents involving obstacles to their free movement. ${ }^{50}$ Any analysis of such incidents must, therefore, rely on the case-law publicly accessible.

The 47 Supreme Court decisions considered here do not always mention the dates of occurrence of the relevant facts, so the date of the decisions is the only one consistently available. This precludes the determination of the evolution of the number of cases of administrative expulsions of EU citizens or family members, or other limitations to their free movement, but the date of the decisions still offers a good indication of the evolutionary pattern of the treatment of such cases by Spanish authorities:

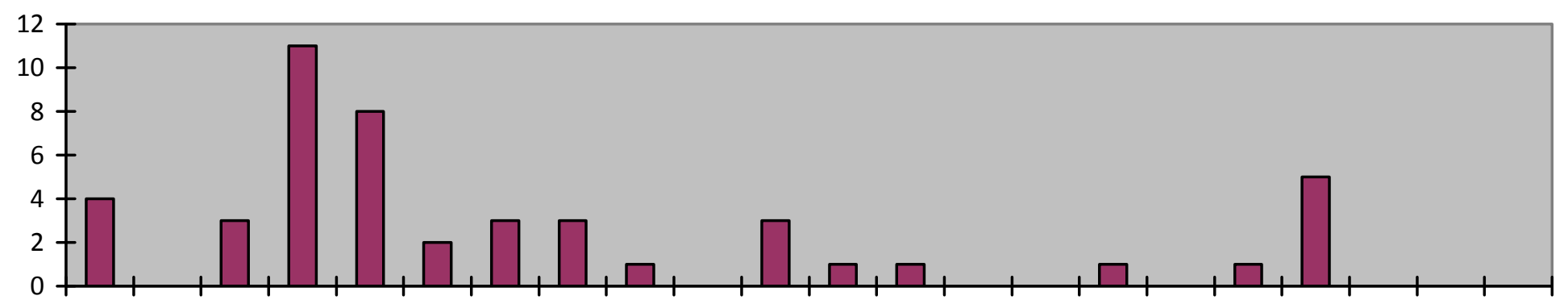

1990199119921993199419951996199719981999200020012002200320042005200620072008200920102011

Number of decisions

Relevant cases only arrived at the Supreme Court in 1990, and the most significant number of cases occurred in 1993 and 1994. Considering that cases may take several years from the date of the facts until they reach the highest judicial instances, these

\footnotetext{
50 The last annual statistics published by the Spanish Ministry of the Interior refer to 2010 and do not contain any figures related to EU citizens and administrative/judicial measures concerning them: <http://www.interior.gob.es/file/52/52707/52707.pdf>, accessed 20 June 2012. Also, the 2012 Statistical Yearbook of Spain contains figures on foreign EU and non-EU citizens (2.1.6), as well as expulsions from national territory (6.2.7), but not the number of EU citizens expelled from national territory: <http://www.ine.es/en/prodyser/pubweb/anuarios_mnu_en.htm>, accessed 20 June 2012.
} 
figures most likely reflect the difficulties which the administrative and lower judicial authorities suffered immediately after Spain’s accession to the EEC in tackling a new legal framework, one requiring a different mindset in relation to a particular category of foreigners. A second significant number of cases were decided in 2008, a reflection of the 2004 and 2007 accessions, as indicated by the nationality of the individuals involved in those cases. ${ }^{51}$

In terms of the outcome of these decisions, it is important to distinguish the number of cases that ended in expulsion and those that did not:

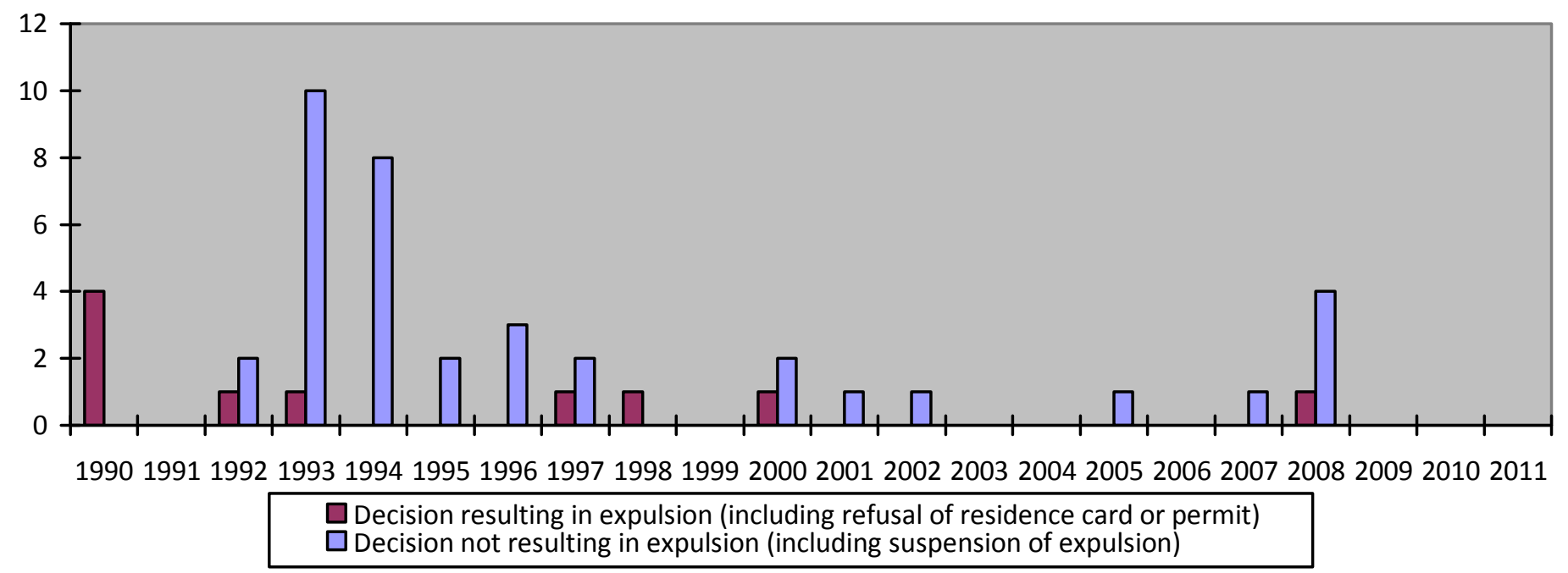

The highest number of decisions resulting in expulsion took place in 1990, in other words, when the Supreme Court first started dealing with free movement cases. That number went down afterwards and has remained very low ever since.

51 STS 4079/2008 (10/07/2008, Romanian), STS 2623/2008 (29/05/2008, Polish), STS 628/2008 (13/02/2008, Bulgarian), and STS 630/2008 (12/02/2008, Romanian). 
In terms of the nationalities of the individuals in question in these decisions, they are as follows: ${ }^{.2}$

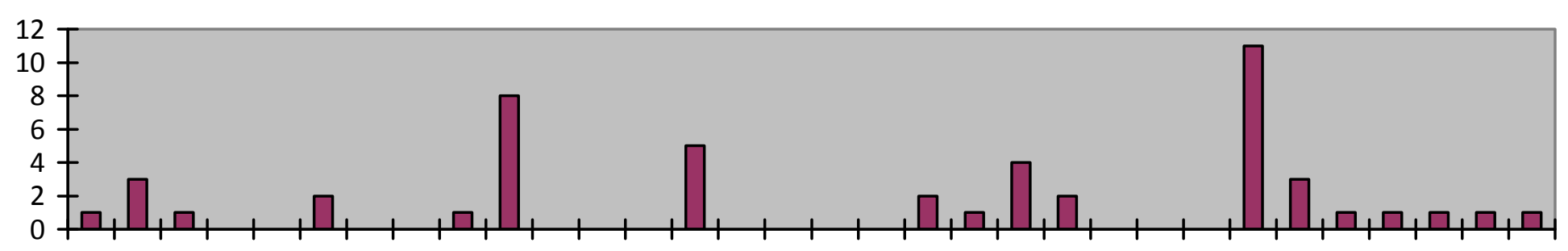

$\square$ No. of indivudals

These figures seem to be mainly a reflection of the relative size of population of the EU member states (in the case of Germany, Italy and UK), the proximity of Spain to other EU member states (in the case of Portugal), and Spanish colonial history and language affinity (in the case of Argentina, Colombia and Cuba).

Although the number of decisions and expulsions considered here is not high, these figures can be safely taken as a mere reflection of the much more substantial overall number of expulsions being ordered and carried out by the Spanish administrative authorities since Spain's accession to the EEC, since only a small proportion of them will have reached the courts and gone all the way to the Supreme Court. As is suggested by the number of decisions confirming expulsions that occurred in 1990, as well as its proportion to the total number of decisions identified, the Spanish judiciary adopted a 'hard line' of case-law when it first started dealing

\footnotetext{
52 The overall number of nationalities considered is higher than the number of decisions identified, since two of the individuals in question held dual nationality (Italian-Argentinean, in STS 6724/1997, 11/11/1997, and Italian-German, in STS (ATS) 5285/1994=18/1994, 28/2/1994).
} 
with cases involving free movement. With time, the number of expulsions has remained very low, suggesting a trend to avoid expulsion wherever possible. These tentative conclusions are supported by the analysis below.

\section{b) From the initial 'hard line' to a more equitable approach}

A strong indicator of how slowly the judiciary adapted to the special status that should be afforded to nationals from other EC/EU member states in the context of migration and the labour market, concerns, first and foremost, the statute which judges have occasionally chosen to apply to the facts in question. In several cases that were decided in the initial years after the accession of Spain to the EEC, the Supreme Court applied the Rights and Freedoms of Foreigners Framework Act in force at the time ${ }^{53}$ rather than the statute applicable to citizens from other member states and their family members (FMA 1986). Although this was often because the latter statute only applied to individuals wishing to carry out a professional activity and it was not proven that the individual in question in the case fell under that personal scope, ${ }^{54}$ in other cases what was behind the refusal of courts to apply FMA 1986 was simply the violation of formalities. ${ }^{55}$ In both types of situations, the lack of convincingly reasoned discussion about the possibility of applying FMA 1986 was a sign of some initial resistance to offering a 'privileged' status to citizens of other EEC member states. To make matters

\footnotetext{
53 'Ley Orgánica 7/1985, de 1 de julio, sobre derechos y libertades de los extranjeros en España'.

54 STS 2420/1990 (15/3/1990), STS 16452/1990 (=7613/1990, 24/10/1990), STS 16389/1990 $(=7742 / 1990,29 / 10 / 1990)$.

55 STS 8404/1990 (=16375/1990, 20/11/1990) and STS 16248/1992 (=2386/1992, 18/3/1992), determining the expulsion not only of those EC citizens who did not wish to work, but also of those who worked but had not fulfilled the legally required formalities, namely requesting or renewing a work permit. This interpretation of the documental requirements established in FMA 1986 was unduly restrictive, as it fundamentally frustrated the aims of this statute: working without a work permit should have already been enough to bring an EC citizen within the scope of FMA 1986, since it indicated that the individual wished to work, irrespective of fulfilling the required formalities or not.
} 
worse, the Spanish Constitutional Court dealt with this matter and favoured the application of the (less favourable) statute generally applicable to foreigners rather than the (more favourable) statute applicable to citizens from other EC member states and their family members, thus giving a constitutional blessing to the lower courts' practice of doubtful legality and compatibility with EC law. ${ }^{56}$

Also, and in the light of the principle of retroactive application of the most favourable rule, FMA 1992 was in fact the applicable legal framework in certain cases decided in the light of FMA 1986, as the former statute had already come into force and was overall more favourable than the latter statute. ${ }^{57}$ In yet other cases, the application of FMA 1986 was denied (or at least not clearly asserted) and FMA 1992 was ignored altogether, although in fact the individual fell within the scope of FMA 1992 and would be better protected by it. ${ }^{58}$

A last example of the initial 'hard line' adopted in cases of free movement of persons concerns the limited consideration offered to the fundamental rights to family and private life. A clear example of this is provided by Decision No. 16248/1992 of

\footnotetext{
${ }^{56}$ Decision No. 2/1992 (13/1/1992).

57 STS 1676/1993 (=18905/1993, 16/3/1993), STS 13474/1993 (30/4/1993), STS 2858/1993 (=13943/1993, 7/5/1993), STS 14268/1993 (=8463/1994, 18/5/1993), STS (ATS) 196/1993 (=4140/1993, 21/9/1993), STS 7727/1993 (16/11/1993), STS (ATS) 3056/1994 (=1848/1994, 24/1/1994), STS (ATS) 1731/1994 (=4574/1994, 27/9/1994), STS 6724/1997 (11/11/1997). At any rate, in these cases there was no significant negative impact on the outcome of the decision, so the application of FMA 1986 (applicable at the time of the facts) could be justified on those grounds.

58 See, for example, STS 13677/1993 (29/1/1993). Considering the criminal record of the British citizen in question, the Rights and Freedoms of Foreigners Framework Act in force at the time entailed an expulsion order. Yet, FMA 1992 brought within its scope those individuals not wishing to work, so it applied to the individual in question. Since more than 10 years had passed since the individual's last criminal conviction, and that was simply a two-year suspended sentence for intended sale of a prohibited drug, the court would have most likely found that expulsion could not be justified on public order or public security grounds. See, also, STS 7948/1993=16963/1993, 23/11/1993. The Portuguese citizen in question was spared expulsion on grounds of insufficient evidence of lack of lawful means of subsistence and of expiry of the period of legal residence in Spain. Yet, the decision was taken on the basis of the Rights and Freedoms of Foreigners Framework Act in force at the time, rather than FMA 1992. Although the decision prevented expulsion, the same result could have been more safely achieved by applying the principle of retroactive application of the most favourable rule. Similarly, STS 21602/1994 (=10235/1994, 23/3/1994).
} 
the Supreme Court, ${ }^{59}$ where it was asserted that a German citizen could be expelled on grounds of not having renewed the required work permit. The fact that the individual in question had a life partnership with a Spanish citizen, as well as a common child with the life partner and another child (both of Spanish nationality), was no impediment to the expulsion. In fact, the Court went so far as to assert that the life partner and children were not affected by the expulsion, and the obligation of payment of alimony could be fulfilled from abroad. This reasoning revealed the rudimentary legal treatment offered to such complex and crucial cases. Later case-law demonstrated much greater sensitivity and respect for individuals’ rights to family and private life, as will be seen below.

These considerations point to a very strict, reductive, formalistic and sometimes even contra legem choice of the applicable legal framework and its interpretation in the initial stages of Spain's integration into the EC and adaptation to EC free movement of workers. The shift from an 'EC free movement of workers' to an 'EU free movement of people', propelled by the 1992 Treaty of Maastricht and reflected in FMA 1992, contributed to a progressively more mature and generous line of case-law by the Spanish judiciary ${ }^{60}$ Also, overall more experience of the judiciary with EU law and the ECHR may have allowed judges to adopt a more sophisticated legal reasoning and adhere more closely to the jurisprudence of the ECJ and ECtHR. ${ }^{61}$

A good indication of the greater awareness of the law applicable to EU citizens and their family members can be seen in the use of the principle of retroactive application of the most favourable rule. For example, in its Decision No. 849/1995, the Supreme Court held that although at the time of the facts Austria was not an EU

\footnotetext{
${ }^{59}$ STS 16248/1992 (=2386/1992, 18/3/1992).

${ }^{60}$ For example, STS 17205/1993 (=8878/1993, 17/12/1993), with a discussion of the evolution of EU law with regard to free movement of persons, with particular reference to the Treaty of Maastricht.

${ }^{61}$ For example, STS 628/2008 (13/2/2008).
} 
member state and therefore the relevant statutory framework was that applicable to non-EU foreigners, by the time the Supreme Court was dealing with the case Austria had acceded to the EU, so FMA 1992 should be applied. ${ }^{62}$ Also, in several 2008 decisions, the Supreme Court asserted that FMA 2007 should apply to Romanian, Bulgarian and Polish citizens, even though at the time of the facts Romania, Bulgaria and Poland were not member states of the EU. ${ }^{63}$

Another example of the tendency to move away from the initial 'hard line' and treat EU citizens and their family members more equitably, relates to cases involving detrimental effects to family and private life. Greater consideration began to be given to personal interests, such as children's health needs, ${ }^{64}$ children's right to be raised by their mother, ${ }^{65}$ the existence of family life in Spain, ${ }^{66}$ and an individual's personal sphere and links to Spain more generally. ${ }^{67}$ This is not to say that any allegation of family ties will guarantee the annulment of an expulsion order, as courts still require evidence of a certain degree of formalisation and strength of those ties. ${ }^{68}$

Yet another good illustration of the gradual (even if slow) process of adaptation of the judiciary to the EU law on free movement of people regards citizens with dual nationality. An example of this reached the Constitutional Court within the framework of a habeas corpus appeal, and concerned an Italian-Argentinean citizen expelled on grounds of being unable to produce the identification documents required of non-EU citizens. ${ }^{69}$ Although focusing on the habeas corpus request rather than on

\footnotetext{
62 STS 849/1995 (=8622/1994, 17/2/1995).

${ }^{63}$ STS 630/2008 (12/2/2008), STS 628/2008 (13/2/2008), STS 2623/2008 (29/5/2008), STS 4079/2008 (10/7/2008). See, also, more recently, STS 4268/2011 (29/6/2011) and STS 4352/2011 (29/06/2011).

${ }^{64}$ STS (ATS) 4008/1993 (=1624/1993, 27/10/1993).

${ }^{65}$ STS 324/2005 (26/1/2005).

${ }^{66}$ Decision appealed in STS 21602/1994 (=10235/1994, 23/3/1994), STS 5986/2000 (18/7/2000), STS 6394/2000 (20/7/2001), STS 8776/2007 (27/11/2007).

${ }^{67}$ STS (ATS) 2660/1992 (=432/1992, 15/7/1992), STS (ATS) 4554/1994 (=1727/1994, 20/9/1994).

${ }^{68}$ STS 6563/2008 (11/9/2008).

${ }^{69}$ Decision 86/1996 (21/5/1996).
} 
the expulsion order, and despite denying the claim for damages, the decision described in some detail the discriminatory and prejudicial treatment which the Spanish authorities had dispensed to this Italian citizen and asserted the violation of the claimant's right to freedom. More recent judicial decisions also indicate considerable awareness of the EU law on this matter, ${ }^{70}$ including the necessary respect for the rules on nationality of other EU member states as dictated by cases such as Micheletti ${ }^{71}$ and Saldanha. ${ }^{72}$

The increasingly cordial line of case-law adopted by Spanish courts is also demonstrated by the suspension of expulsion orders concerning EU citizens. In a series of cases decided by the Supreme Court throughout the $1990 \mathrm{~s}^{73}$ judges consistently argued in favour of the lack of public interest to justify the immediate expulsion of the EU citizen in question in the proceedings, consequently ordering the suspension of the expulsion order.

A final example of courts' positive disposition towards EU law concerns the wide referencing to free movement legislation and jurisprudence, including mentions of a range of directives on free movement of workers up to the Free Movement Directive ${ }^{74}$ to the Treaty of Maastricht ${ }^{75}$ and to ECJ decisions dealing with dual

\footnotetext{
${ }^{70}$ See, for example, STS 6724/1997 (11/11/1997), again a case of an Italian-Argentinean, whose Italian nationality was recognised by the Supreme Court as valid, despite the individual's last domicile having been in Argentina.

${ }^{71}$ Case C-369/90, Mario Vicente Micheletti and others v Delegación del Gobierno en Cantabria, 7/7/1992.

72 Case C-122/96, Stephen Austin Saldanha and MTS Securities Corporation v Hiross Holding AG, 2/10/1997.

${ }^{73}$ STS (ATS) 2660/1992 (=432/1992, 18/3/1992), STS (ATS) 2706/1992 (=433/1992, 15/7/1992), STS (ATS) 196/1993 (=4140/1993, 21/9/1993), STS (ATS) 4008/1993 (=1624/1993, 27/10/1993), STS (ATS) 3056/1994 (=1848/1994, 24/1/1994), STS (ATS) 5285/1994 (=18/1994, 28/2/1994), STS (ATS) 1442/1994 (=4495/1994, 11/7/1994), STS (ATS) 4554/1994 (=1727/1994, 20/9/1994), STS (ATS) 1740/1994 (=4447/1994, 26/9/1994), STS (ATS) 1731/1994 (=4574/1994, 27/9/1994), STS 849/1995 (=8622/1994, 17/2/1995), STS 6320/1995 (12/12/1995), STS 1356/199 (4/3/1996), STS 790/1996 (9/12/1996), STS (ATS) 6685/1997 (20/1/1997).

${ }^{74}$ STS 17205/1993 (=8878/1993, 17/12/1993), STS 8776/2007 (27/11/2007).

${ }^{75}$ STS 17205/1993 (=8878/1993, 17/12/1993).
} 
nationality, ${ }^{76}$ expulsion requirements ${ }^{77}$ and, more generally, EU citizenship ${ }^{78}$ cases. EU citizenship and its judicial development, in particular, are topics that have captured the interest of Spanish legal scholarship as well (Navarro 2007).

\section{c) The grounds for limitation of free movement in Spanish case-law}

Spanish case-law, as a rule, does not explore the notions of public order, public security or public health. Whilst the lack of a conceptual framework in the application of these notions is not exclusive to Spain, it unwisely leaves too much discretion to courts and administrative authorities of the EU member states where this occurs (Carrera and Atger, 2009: 10-11). Spanish decisions tend to assume a certain scope of these notions and follow the interpretation adopted by CJEU jurisprudence. For example, the Supreme Court has argued that the conduct of the individual being expelled needs to constitute a real and sufficiently serious threat to a fundamental interest of society, ${ }^{79}$ the scope of free movement of persons should be interpreted widely and any restriction to that free movement should be interpreted strictly. ${ }^{80}$

The Supreme Court has thus increasingly and expressly followed the line of jurisprudence constituted by cases such as Bonsignore, ${ }^{81}$ Rutili, $^{82}$ Royer, ${ }^{83}$ Bouchereau, ${ }^{84}$ Donatella Calfa, ${ }^{85}$ MRAX, ${ }^{86}$ Baumbast $^{87}$ Oulane, ${ }^{88}$ and Tas-Hagen

\footnotetext{
${ }^{76}$ STS 6724/1997 (11/11/1997).

${ }^{77}$ STS $1715 / 2000$ (4/3/2000), STS 2032/2000 (14/3/2000), STS 6394/2000 (20/7/2001), STS 628/2008 $(13 / 2 / 2008)$

${ }^{78}$ STS $628 / 2008(13 / 2 / 2008)$.

${ }^{79}$ STS $1715 / 2000$ (4/3/2000), relating to serious labour-related offences as public order violations. To the same effect, see also STS 6394/2000 (20/7/2001).

${ }^{80}$ STS 628/2008 (13/2/2008), concluding with the non-expulsion of the individual in question.

${ }^{81}$ Case 67/74, Carmelo Angelo Bonsignore v Oberstadtdirektor der Stadt Köln, 26/2/1975.

${ }^{82}$ Case 36/75, Roland Rutili v Ministre de l'intérieur, 28/10/1975.

${ }^{83}$ Case 48/75, Jean Noël Royer, 8/4/1976.

${ }^{84}$ Case 30/77, Régina v Pierre Bouchereau, 27/10/1977.

${ }^{85}$ Case C-348/96, Criminal proceedings against Donatella Calfa, 19/1/1999.
} 
and Tas, ${ }^{89}$ either with the intention of confirming or denying an obstacle to free movement of persons. Whilst this may indicate the importance and reception of CJEU jurisprudence in the domestic context and a smooth application of the principle of supremacy of EU law, it may also, more prosaically, reflect a certain lack of commitment to explore these notions, as well as lack of knowledge and awareness of their true extent and characteristics.

More strikingly, some decisions do not refer to any precise expulsion ground at all, ${ }^{90}$ other decisions do not state clearly the ground in question but offer some hints as to the relevant ground, ${ }^{91}$ and yet other decisions refer (more or less explicitly) to more than one ground without offering an objective and reasoned analysis of the choice in question. ${ }^{92}$ In relation to those decisions that refer more or less clearly to a particular ground, one can conclude that: the notion of public security is only mentioned with regard to individuals who possess a criminal record; ${ }^{93}$ the notion of public health only arises in cases involving offences against public health (which, although not explicitly, seem to invariably refer to criminal offences involving drug addiction or trafficking); ${ }^{94}$ and the notion of public order seems to work as a defaultcum-residual category, encompassing circumstances as diverse as lack of residence or

\footnotetext{
${ }^{86}$ Case C-459/99, Mouvement contre le racisme, l'antisémitisme et la xénophobie ASBL (MRAX) v État belge, 25/7/2002.

${ }^{87}$ Case C-413/99, Baumbast and $R v$ Secretary of State for the Home Department, 17/9/2002.

${ }^{88}$ Case C-215/03, Salah Oulane v Minister voor Vreemdelingenzaken en Integratie, 17/2/2005.

${ }^{89}$ Case C-192/05, K. Tas-Hagen, R.A. Tas v Raadskamer WUBO van de Pensioen- en Uitkeringsraad, 26/10/2006.

${ }^{90}$ STS 790/1996 (9/12/1996), STS 6724/1997 (11/11/1997), STS 324/2005 (26/1/2005).

${ }^{91}$ STS (ATS) 2660/1992 (=432/1992, 15/7/1992), STS (ATS) 2706/1992 (=433/1992, 15/7/1992), STS 13677/1993 (29/1/1993), STS 1676/1993 (=18905/1993, 16/3/1993), STS (ATS) 8116/1998 (22/6/1998), all most likely justifiable on grounds of public order.

${ }_{92}$ STS 16452/1990 (=7613/1990, 24/10/1990) and STS 21602/1994 (=10235/1994, 23/3/1994), in relation to public order and public security; STS 2032/2000 (14/3/2000), in relation to public order and public health.

${ }_{93}$ STS 16452/1990 (=7613/1990, 24/10/1990), STS 21602/1994 (=10235/1994, 23/3/1994).

94 STS 13474/1993 (30/4/1993), STS 2032/2000 (14/3/2000), STS 8776/2007 (27/11/2007), STS $6563 / 2008(11 / 9 / 2008)$.
} 
work permits or violation of other similar formalities, ${ }^{95}$ lack of lawful means of subsistence ${ }^{96}$ and commission of criminal offences. ${ }^{97}$ Also striking in the case-law of the Supreme Court is that the same circumstances seem to fall under the scope of different grounds, which leads to more than one ground applying, including both public order and public security (in relation to documental formalities and past criminal convictions) ${ }^{98}$ and both public order and public health (in relation to a conviction for a crime against public health). ${ }^{99}$

This state of affairs is arguably both a reflection of, and a contribution to, the normative and conceptual overlapping and blurring of all three grounds. The observations above in Section 3 are thus confirmed, thereby highlighting the need for much more work for a more effective legislative, judicial and doctrinal distinction between the notions of public order, public security and public health.

\section{d) New and accession member states}

The accession of new member states to the EU has constituted yet another challenge to administrative and judicial authorities getting to grips with changes to the factual

\footnotetext{
95 STS 2420/1990 (15/3/1990), STS 16389/1990 (=7742/1990, 29/10/1990), STS 16248/1992 (=2386/1992, 18/3/1992), STS 2858/1993 (=13943/1993, 7/5/1993), STS (ATS) 196/1993 $(=4140 / 1993,21 / 9 / 1993)$, STS (ATS) $4008 / 1993 \quad(=1624 / 1993,27 / 10 / 1993)$, STS $13779 / 1993$ $(=2571 / 1993,23 / 4 / 1993)$, STS 7948/1993 (=16963/1993, 23/11/1993), STS 17205/1993 $(=8878 / 1993$, 17/12/1993), STS (ATS) 3056/1994 (=1848/1994, 24/1/1994), STS (ATS) 5285/1994 $(=18 / 1994$, 28/2/1994), STS 20515/1994 (=12286/1994, 31/5/1994), STS (ATS 1442/1994 (=4495/1994, 11/7/1994), STS (ATS) 4554/1994 (=1727/1994, 20/9/1994), STS (ATS) 1740/1994 $(=4447 / 1994$, 26/9/1994), STS (ATS) $1731 / 1994$ (=4574/1994, 27/9/1994), STS 6320/1995 (12/12/1995), STS 125/1996 (16/1/1996), STS 1356/1996 (4/3/1996), STS (ATS) 6685/1997 (20/1/1997), STS (ATS) 7151/1996 (10/10/1997), STS 5986/2000 (18/7/2000), STS 2434/2002 (5/4/2002).

96 STS 8404/1990 (=16375/1990, 20/11/1990), STS 7948/1993 (=16963/1993, 23/11/1993), STS (ATS) $4554 / 1994$ (=1727/1994, 20/9/1994), STS 849/1995 (=8622/1994, 17/2/1995), STS 2434/2002 $(5 / 4 / 2002)$.

${ }^{97}$ STS 14268/1993 (8463/1994, 18/5/1993), STS 17205/1993 (=8878/1993, 17/12/1993), STS (ATS)

3056/1994 (=1848/1994, 24/1/1994), STS 1715/2000 (4/3/2000), STS 6394/2000 (20/7/2001).

${ }^{98}$ STS 16452/1990 (=7613/1990, 24/10/1990), STS 21602/1994 (=10235/1994, 23/3/1994).

${ }^{99}$ STS 2032/2000 (14/3/2000).
} 
situation and the legal implications of those changes. The accession treaties of the member states that acceded to the EU in 2004 and 2007 offered the EU 15 the possibility of imposing a transition period regarding the free movement of persons. In this respect, and on account of (internal and external) political and (internal) trade union positions, Spain has adopted an 'intermediate position', that is, it has in the first instance opted for resorting to the transition period (in relation to both the 2004 and the 2007 acceding member states), but has chosen not to prolong it to the furthest extent possible (Turrión, 2008). At any rate, with the increasing number of Eastern European citizens arriving in Spain, the new legal device of 'transition period' became a spanner in the Spanish administrative works.

It has taken a few Supreme Court decisions on this matter to clarify that the free movement of persons' transition period, specifically with regard to Romania and Bulgaria, did not prevent citizens from these countries from entering Spanish territory without previous authorisation. ${ }^{100}$ These decisions went on to make it clear that these EU citizens could only be subject to an administrative control of registration, the omission or irregularity of which did not warrant expulsion, and that the transition period applied only to the right to work for another, but not to independent workers, or to the right to circulate or to the right to reside.

100 STS 630/2008 (12/2/2008), STS 628/2008 (13/2/2008), STS 4079/2008 (10/7/2008), STS 6750/2008 (5/11/2008). 


\section{e) Broadening the scope of protection and preventing reverse discrimination}

Interestingly, the legal framework created to protect the rights of EU citizens and family members exercising their right to free movement, has also been used to advance the claims of non-EU citizens with (actual or potential) family or common life links with Spanish citizens who have not exercised their right to free movement. As discussed above (Section 2), the original version of Article 2 FMA 2007 was challenged and amended to broaden the personal scope of FMA 2007 so as to include Spanish citizens and their non-EU relatives, even when the former have not exercised their right to free movement. ${ }^{101}$ This was already the case under the previous statutory frameworks, ${ }^{102}$ and constituted a necessity on grounds of ensuring an equitable and non-discriminatory treatment between Spanish citizens and other EU citizens, namely to prevent cases of reverse discrimination (Sánchez, 2007: 917-24; González Viada, 2009). Consequently, requests for family reunification presented by Spanish citizens who have not exercised their right to free movement are now consensually assessed in light of FMA 2007..$^{103}$

Examples of the usefulness of these rules abound in the Supreme Court caselaw. Cases pertaining to non-EU ascendants of Spanish (generally naturalised) citizens have become relatively common in Spanish case-law, namely in relation to Colombian ${ }^{104}$ and Ecuadorean ${ }^{105}$ citizens. Moreover, in Decision No. 7151/1996, the

\footnotetext{
${ }^{101}$ STS 4259/2010 (1/6/2010).

102 Article 2 FMA 2003, Article 2 RD766/1992, Article 2(2) RD 1089/1986.

103 'Instrucción DGI/SGRJ/03/2010' (4/11/2010).

${ }^{104}$ STS 8359/2011 (22/11/2011), STS 8739/2011 (16/12/2011).

${ }^{105}$ STS 7339/2011 (20/10/2011), STS 8677/2011 (23/11/2011).
} 
Supreme Court dealt with the appeal lodged by a Cuban citizen, who had been married to a Spanish citizen and was going to marry another Spanish citizen, against the administrative decision of revoking his EU family member residence card. ${ }^{106}$ Although his appeal was denied and the revocation of the card was confirmed, this was not done on material grounds, but on procedural grounds (the new circumstance of a potential marriage with another Spanish citizen could not be taken into consideration, since the appeal to the Supreme Court was only on matters of law). This means that the Court did not deny the possibility of a non-EU citizen, currently not a family member of an EU citizen, benefiting from the statute applicable to EU citizens and their family members. Also, in Decision No. 5986/2000, the Supreme Court dealt with a request to suspend an administrative decision of expulsion lodged by a non-EU citizen who was the mother-in-law and grandmother of Spanish citizens. ${ }^{107}$ The appellant invoked the serious and irreparable damage which the expulsion would cause to her family and professional life, and the Supreme Court confirmed the irreparable damage that the expulsion, and consequent interruption of family life and economic assistance, would indeed cause. In a third case, the Supreme Court dealt with the expulsion of a Colombian citizen who married a Spanish citizen after the expulsion order had been issued by the Spanish authorities. ${ }^{108}$ The Supreme Court rightly asserted that the legal framework applicable to the facts had changed, and the Colombian citizen could only be expelled in accordance with FMA 1992. The expulsion order was consequently annulled, since the lack of a residence card was an insufficient ground. Finally, in a case involving a Brazilian mother of a child of (presumed) Spanish nationality, the Supreme Court asserted the right of the child - as

\footnotetext{
106 STS (ATS) 7151/1996 (10/10/1997).

107 STS 5986/2000 (18/7/2000).

108 STS 2434/2002 (5/4/2002).
} 
a Spanish citizen - to be raised by the mother and not having to leave the country to be able to enjoy that right. ${ }^{109}$ Although not explicitly applying the statutory framework applicable to EU citizens and their family members, and despite the insufficient legal reasoning to substantiate the decision, the outcome was satisfactory and benefited the non-EU family member of a Spanish citizen who had not exercised the right to free movement.

This line of case-law is consistent not only with the tradition of domestic statutory provisions, but also with developments in the jurisprudence of the CJEU, whereby non-EU citizens have also seen their rights increasingly widened and protected. ${ }^{110}$ Still, it is striking that the Supreme Court went down such bold path even before the CJEU took decisions along the same lines.

\section{Conclusion}

Since Spain's accession to the EC in 1986, the Spanish administrative and judicial authorities have had to adapt to a radically different way of dealing with foreigners, namely those from other member states of the EC/EU and their family members. This has been a slow and sometimes rocky path.

Despite the judicial proceedings initiated by some NGOs and the European Commission contesting statutory provisions arguably falling short of the EU law acquis, the Spanish legislature has generally fulfilled its obligations in the field of free

\footnotetext{
109 STS 2434/2002 (5/4/2002).

${ }^{110}$ For example, Case C-459/99, Mouvement contre le racisme, l'antisémitisme et la xénophobie ASBL (MRAX) and État belge, 25/7/2002; Case C-413/99, Baumbast and R. v Secretary of State for the Home Department, 17/9/2002; Case C-200/02, Zhu and Chen v Secretary of State for the Home Department, 19/10/2004; Case C-127/08, Blaise Baheten Metock and Others v Minister for Justice, Equality and Law Reform, 25/7/2008; Case C-34/09, Gerardo Ruiz Zambrano v Office national de l'emploi (ONEm), 8/3/2011.
} 
movement of people and the Free Movement Directive has been for the most part well implemented. In most instances where that was not the case, courts have used every opportunity to effectively introduce the necessary corrections. This is not to say that the statutory framework currently in force is perfect, since several aspects requiring improvement have been highlighted throughout this article. Still, the key issues surrounding free movement of people in Spain have not resided so much in the quality of the statutory framework, but more in the decision-making of administrative and judicial authorities.

Indeed, the Spanish Supreme Court decisions identified reveal a range of decisions of dubious legality, creating obstacles to free movement. The initial contact with cases of free movement of citizens from other EC member states produced several decisions with disproportionately negative outcomes and, most importantly, of poor legal quality. Problems included the wrong choice of statute, placing undue importance on fulfilment of legal formalities, and insufficient consideration for individuals' fundamental rights to family and private life. Improvements on all these and other fronts are patent in more recent decisions of the Supreme Court: the principle of retroactive application of the most favourable rule is more widely acknowledged and respected; the violation of legal (documental) formalities no longer warrants any penalty beyond a fine; procedural safeguards and effective protection are consistently ensured; individuals’ personal and family circumstances are dealt with more equitably; there is greater readiness to suspend orders of expulsion; and there is a generally stronger adherence to CJEU jurisprudence.

The notions of public policy, public security and public health, and how one chooses to interpret them and apply them to the facts, have obviously played a key role in this process. The lack of statutory detail in relation to the content of these 
notions has left wide room for manoeuvre to the administration and courts. The latter have not striven for a sophisticated understanding and interpretation of these notions. On the contrary, these notions are not only applied interchangeably, but they also seem to be used without sufficient consistency or awareness of their content, and are sometimes not used at all to justify an obstacle to free movement. Despite this being, at least partially, a reflection of the state of affairs at the level of the CJEU jurisprudence, more care and precision is required in Spanish decision-making in this regard.

Whilst the current state of affairs is overall satisfactory, several aspects of the statutory framework in force could still be improved. Also, as new states accede to the EU, the universe of EU citizens expands and the EU law acquis in this field evolves, Spanish authorities will have to carry on making an effort to adapt to the changes to the factual and legal contexts. In any case, it is clear that the Spanish legal framework does distinguish beyond any doubt between EU citizens and their family members, on the one hand, and other foreigners, on the other. The broader, and more crucial, question remains: should not EU citizens be treated simply as any other national, subject to criminal sanctions but not expulsion (Icard, 2009: 79-80)? This, however, is not a question that Spain can answer alone.

\section{Bibliography}

Carrera, S. and A. F. Atger (2009). Implementation of Directive 2004/38/EC in the context of EU Enlargement: A proliferation of different forms of citizenship? Special Report, Centre for European Policy Studies.

Closa, C. and P. M. Heywood (2004). Spain and the European Union. London, Palgrave Macmillan. 
Gonzalez, L. E. and R. MacBride (2000). "Fortress Europe: Fear of immigration? Present and future of immigration law and policy in Spain." U.C. Davis Journal of International Law \& Policy 6(Spring): 153.

González Viada, N. (2009). "La libre circulación de ciudadanos de la Unión Europea en España: Análisis crítico del Real Decreto 240/2007, de 16 de febrero." Noticias de la Unión Europea XXV(292): 23-37.

González-Enríquez, C. (2009). "Spain, the cheap model: Irregularity and regularisation as immigration management policies." European Journal of Migration and Law 11(2): 139-157.

González-Enríquez, C. (2011). The making of immigration policies in Spain 19852010. In Spain in the European Union: the First Twenty-Five Years (19862011). J. Roy and M. Lorca-Susino (eds.), Jean Monnet Chair, University of Miami / Miami-Florida European Union Center of Excellence: 117-136.

González-Enríquez, C. and A. Triandafyllidou (2009). "Introduction: Comparing the new hosts of southern Europe." European Journal of Migration and Law 11(2): 109-118.

Icard, P. (2009). La citoyenneté européenne altérée: L'expulsion pour atteinte à l'ordre et à la sécurité publics. In Une citoyenneté européenne dans tous ses «États». P. Icard (ed.). Dijon, Éd. universitaires de Dijon: 59-85.

Mullerat, R. (2011). How Spain implements European Law. In Spain in the European Union: the First Twenty-Five Years (1986-2011). J. Roy and M. Lorca-Susino (eds.), Jean Monnet Chair, University of Miami / Miami-Florida European Union Center of Excellence: 87-99.

Navarro, E. C. (2007). "La jurisprudencia del TJCE en materia de ciudadanía de la Unión: Una interpretación generosa basada en la remisión al Derecho nacional y en el principio de no discriminación por razón de la nacionalidad." Revista de Derecho Comunitario Europeo 28(Septiembre/Diciembre): 883-912.

Peinado, M. D. B. (2007). "La transposición en Derecho español de la normativa comunitaria sobre libre circulación y residencia de ciudadanos de la Unión y miembros de su familia: El Real Decreto 240/2007 de 16 de febrero." Revista de Derecho Comunitario Europeo 27(mayo/agosto): 595-622.

Sánchez, S. I. (2007). "Dos cuestiones suscitadas por la transposición española de la Directiva 2004/38/EC/CE a través del RD 240/2007: el régimen aplicable a los ascendientes de españoles y la extensión a las parejas registradas del concepto «miembros de la familia de los ciudadanos de la Unión»." Revista de Derecho Comunitario Europeo 28(septiembre/diciembre): 913-939.

Turrión, R. F. (2008). "La otra Europa que viene: Europeos del Este en España." Revista Cidob d'Afers Internacionals 84(Diciembre): 49-64.

Vilà-Costa, B. (2011). The legal added value of European membership: Some issues of the Spanish case. In Spain in the European Union: the First Twenty-Five Years (1986-2011). J. Roy and M. Lorca-Susino (eds.), Jean Monnet Chair, University of Miami / Miami-Florida European Union Center of Excellence: 101-116. 